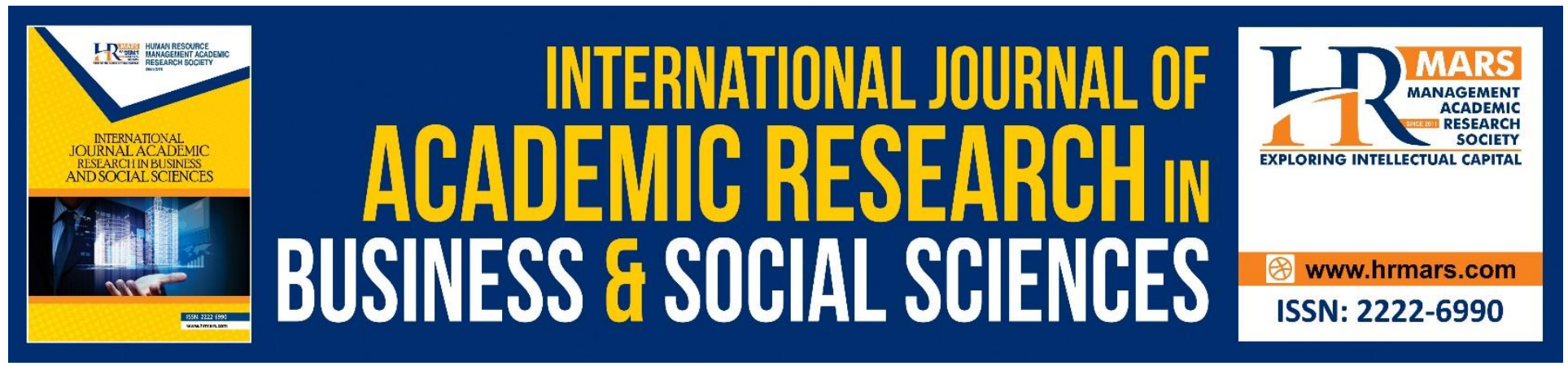

\title{
Managing Food Security in Malaysia: A Resource-Based View (RBV) Analysis
}

Fakhrul Anwar Zainol, Wan Norhayate Wan Daud, Zulhamri Abdullah, Wan Fauziah Wan Yusoff

To Link this Article: http://dx.doi.org/10.6007/IJARBSS/v8-i12/5082

DOI: $10.6007 /$ IJARBSS/v8-i12/5082

Received: 29 Nov 2018, Revised: 21 Dec 2018, Accepted: 29 Dec 2018

Published Online: 30 Dec 2018

In-Text Citation: (Zainol, Daud, Abdullah, \& Yusoff, 2018)

To Cite this Article: Zainol, F. A., Daud, W. N. W., Abdullah, Z., \& Yusoff, W. F. W. (2018). Managing Food Security in Malaysia: A Resource-Based View (RBV) Analysis. International Journal of Academic Research in Business and Social Sciences, 8(12), 896-902.

Copyright: (c) 2018 The Author(s)

Published by Human Resource Management Academic Research Society (www.hrmars.com)

This article is published under the Creative Commons Attribution (CC BY 4.0) license. Anyone may reproduce, distribute, translate and create derivative works of this article (for both commercial and non-commercial purposes), subject to full attribution to the original publication and authors. The full terms of this license may be seen

at: http://creativecommons.org/licences/by/4.0/legalcode

Vol. 8, No. 12, 2018, Pg. 896 - 902

http://hrmars.com/index.php/pages/detail/IJARBSS

JOURNAL HOMEPAGE

Full Terms \& Conditions of access and use can be found at http://hrmars.com/index.php/pages/detail/publication-ethics 


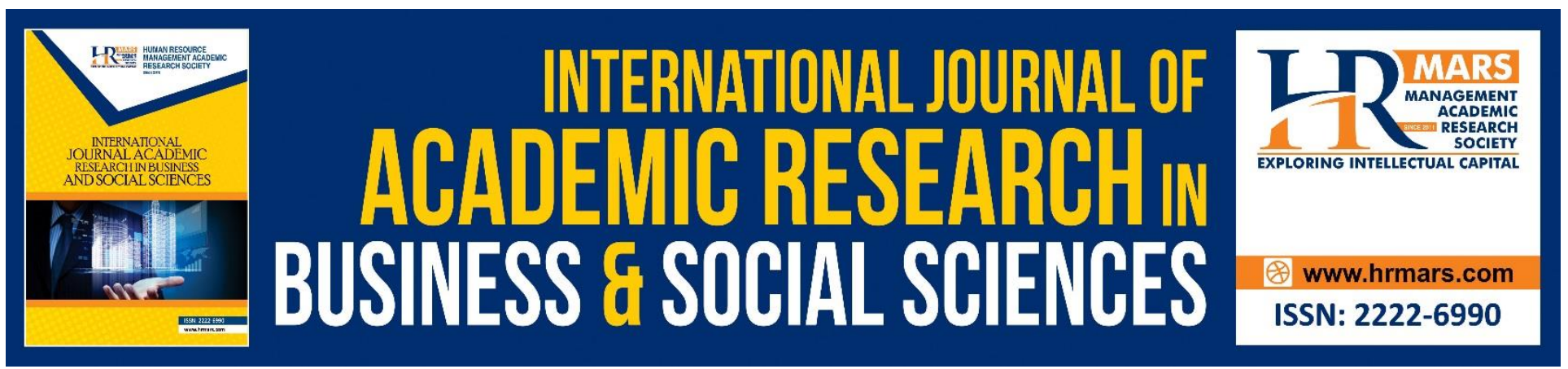

\title{
Managing Food Security in Malaysia: A Resource- Based View (RBV) Analysis
}

\author{
Fakhrul Anwar Zainol \\ Faculty of Economics \& Management Sciences, Universiti Sultan Zainal Abidin \\ Chua Kim Aik, Green World Genetics Sdn Bhd \\ Wan Norhayate Wan Daud \\ Faculty of Economics \& Management Sciences, Universiti Sultan Zainal Abidin \\ Zulhamri Abdullah \\ Communication Department, FBMK, Universiti Putra Malaysia

\section{Wan Fauziah Wan Yusoff} \\ Faculty of Technology Management \& Business, Universiti Tun Hussein Onn Malaysia
}

\section{ABSTRACT}

This study was carried out in a case study approach with intended research focus of examining the impact of the intangible resources and tangible resources on the growth of the seed industry in Malaysia. The strategic management of food security in Malaysia became the main concern in this study. It is clear that food security has become an important focus and widely debated issue built on four dimensions; food availability, food stability, food accessibility and food utilization. In the Resource-Based View (RBV) perspective, the focus has been directed towards business start-up as a resource acquisition process, where the availability of unique resources is presumed to promote industry development.

The findings revealed that a focus on both tangible and intangible resource development that includes, funds, land, technology, a skilled workforce, policy and brands reputation is likely to generate the most growth within the seed industry. In addition, firms with valuable resources stand a better chance of growth but due to some limitations, government supports are needed, particularly on intangible resources. The resource-based view (RBV) of the firm suggests that positive competitive outcomes are largely attributable to an organizations' idiosyncratic resources. Hence, this study will help to link and identify the capabilities of both tangible and intangible resouces to 
INTERNATIONAL JOURNAL OF ACADEMIC RESEARCH IN BUSINESS AND SOCIAL SCIENCES

Vol. 8, No. 12, Dec, 2018, E-ISSN: 2222-6990 @ 2018 HRMARS

fullfill RBV requirements in order to develop more effective support system for seed industry in Malaysia.

\section{INTRODUCTION}

Agriculture has been and will remain an important sector of Malaysia's national and our global economy. It provides the ultimate source of essential food and fiber for the population (Nasir 2010). However, seed is the most important fundamental input of the total supply chain in Agriculture. It plays a major role in contributing to the success of farm productivity (Melor, 2003). High quality seed alone plays the most important role in increasing agricultural output and is capable of increasing productivity as high as 20 per cent (Singh, Asokan and Asopa, 1990). However, the seed industry in Malaysia is not well develop like Europe, Japan and United State, in fact is lagging behind, still at the early phase of development (Melor, 2003). In view of this, focus should be on developing of high quality seeds. A robust seed system is needed to guarantee the sustainability of agriculture and to ensure that products of modern plant breeding are widely available. This will eventually lead to the achievement of self-sufficiency in agricultural production and improved food quality and food security.

\section{What is Resource based-view (RBV)?}

The resource-based view or RBV (Penrose, 1959; Wernerfelt, 1984) was developed by strategic management theorists to understand a firm's internal capability. This perspective implies that organizations consist of heterogeneous bundles of resources. By combining such bundles in specific ways, a firm can create unique capabilities and develop sustainable competitive advantage. Resources are defined as both tangible and intangible assets controlled by the firm. Resource typologies have been suggested both within and outside the resource based perspective, to include physical, human and organizational capital (Barney, 1991), financial, reputation and technological resources, and social capital (Greene \& Brown, 1997).

By using the resources based-view (RBV) theory, this study investigates the impact of tangible and intangible assets of the seed industry in Malaysia. This study is intended to extend the resources based-view theory by emphasizing the factors that contribute to the success of firm performance. The created construct will provide new insights in the theory of resources based-view to enhance the competitive advantage model (Barney, 1991).

\section{RESEARCH METHOD}

The population and sample in this study consists of members of the National Seeds Association Malaysia. The sample size of this qualitative research is small, but it provides an extensive amount of information from the comments of the respondents (Maxwell, 1996). These descriptions provide details of the context and meaning of events and situations for those involved and those investigating (Geertz, 1983). By pursuing a multiple case study design, the samples should share the same characteristics across all cases (Farquhar, 2012). Thus, in this study, the sample size of 12 selected experts was divided into three clusters, namely plant breeders, traders or managers and seed production experts. Each cluster was represented by 4 members.

\section{FINDINGS}


INTERNATIONAL JOURNAL OF ACADEMIC RESEARCH IN BUSINESS AND SOCIAL SCIENCES Vol. 8, No. 12, Dec, 2018, E-ISSN: 2222-6990 C 2018 HRMARS

This section discusses the findings of the research data in relation of the second research question: To what extent is the impact of the intangible resources and tangible resources on the growth of the seed industry in Malaysia? There were three themes involved in this analysis to answer the research question. Firstly, respondent's view of the seed industry, secondly, seed production activities and, lastly, the most important resources of seed industry.

Accordingly, a detailed breakdown of the interview responses for this research question is provided in Table 1 below.

Table 1: Summary of the Findings

\begin{tabular}{|c|c|c|c|c|}
\hline Themes & Sub-themes & Codes & $\begin{array}{l}\text { Respondents } \\
\text { (Verbatim) }\end{array}$ & $\begin{array}{c}\text { Industry/ } \\
\text { Background }\end{array}$ \\
\hline \multirow{2}{*}{$\begin{array}{c}\text { Seed } \\
\text { Industry }\end{array}$} & $\begin{array}{l}\text { - View of the Seed } \\
\text { Industry }\end{array}$ & VaSI & $1,2,3 \& 4$ & $\begin{array}{c}\text { Plant Breeder (2), } \\
\text { Production } \\
\text { Expert (2) }\end{array}$ \\
\hline & $\begin{array}{l}\text { - Seed Production } \\
\text { Activities }\end{array}$ & SPA & $1,2 \& 4$ & $\begin{array}{c}\text { Plant Breeder (1), } \\
\text { Production } \\
\text { Expert (2) }\end{array}$ \\
\hline $\begin{array}{l}\text { Tangible } \\
\text { Resources }\end{array}$ & $\begin{array}{l}\text { - Fund } \\
\text { - Land } \\
\text { - Technological } \\
\text { - Organization } \\
\text { structure }\end{array}$ & TR & $\begin{array}{c}1,2,3,4,5,9 \& 11 \\
1,2,3,4,5 \& 12 \\
2,3,6,7 \& 8 \\
3,4 \& 9\end{array}$ & $\begin{array}{c}\text { Plant Breeder (4), } \\
\text { Production } \\
\text { Expert (4) } \\
\& \\
\text { Trader (4) }\end{array}$ \\
\hline $\begin{array}{l}\text { Intangible } \\
\text { Resources }\end{array}$ & $\begin{array}{l}\text { - Human Capital } \\
\text { - Knowledge } \\
\text { - Inbred Line } \\
\text { - Climate } \\
\text { - Innovation } \\
\text { - Reputation } \\
\text { - Weather }\end{array}$ & IR & $\begin{array}{c}1,2,3,4 \& 5 \\
2,3 \& 9 \\
1,4,5,8,10,11 \& 12 \\
1,4,5 \& 9 \\
3 \& 9 \\
7 \\
1,2,3,4,5,9 \& 11\end{array}$ & $\begin{array}{c}\text { Plant Breeder (4), } \\
\text { Production } \\
\text { Expert (4) } \\
\& \\
\text { Trader (4) }\end{array}$ \\
\hline
\end{tabular}

From the quotations above, it can be summarized that developing seeds is a very expensive process. It requires a lot of funds and it is time consuming. Respondents mentioned that besides funds and time, we also need to have the knowledge and an inbred line to produce good hybrid seed. 
To sustain this process, we also need to have sufficient technology. In order to market the product, we need to have a good reputation of producing quality seed.

According to the view from participants involve in this study, seed production activities in Malaysia have been initiated by the Ministry of Agriculture and Agro-based Industry (MAO). MAO's initiative EPP 14 is to strengthen the integrated seed sector in Malaysia and ensure the seed supply for the country, with an aim to have enough for food production. Its focus is on increasing local seed production and reducing seed importation; producing superior varieties that are able to compete with varieties in the global seed market and increasing the availability of quality seeds and planting materials in the market. However, there are very few seed production orders as there are not many seed companies in Malaysia.

In term of resources, which are the basic unit of analysis for RBV, they can be defined as those assets that are tied semi-permanently to the firm. All respondents looked at two types of resources, tangible and intangible resources. This includes financial, physical, human, commercial, technological, and organizational assets used by firms to develop, manufacture, and deliver products and services to its customers. Tangible resources can be classified as financial or physical, such as, funding, technology and organization structure and intangible resources, such as employee's knowledge, experiences and skills, the firm's reputation, weather, an inbred line and innovation.

\section{CONCLUSION}

To realise a sustainable competitive growth in an industry, requires a well planned strategy (Porter, 1991; 1996). This is a fundamental issue in the field of strategic management (Rumelt, Schendel and Teece, 1991). In order to have a sustainable competitive advantage, new goals need to be more efficient and a commitment to a continuous well planned strategy is essential (Porter, 1991; 1996). The development of the field of strategic management within the last two decades has been very active (Hoskisson, Hitt, Wan and Yiu, 1999). New Management Strategy literature has provided a number of models of strategic change that might be designed and implemented. A popular one is the Resource-Based View (RBV) theory which is evident by its diffusion throughout strategic management literature. The theory can be used by a firm to examine whether the firm possesses any of the required resources which could allow the firm to fomulate a good management strategy. Particularly firms or industries which are new and underperforming.

For seed to be considered a valuable and rare resource, it should be high yielding, disease resistant, easy to grow and well adaptated to local climate conditions. To create new varieties of seed takes time and needs the right inbred line, which Malaysia, as a country with such a unique biodiversity, could provide from resources, which other countries might not have. This contributes to the creation of valuable variables that enable a firm to formulate competitive strategy. This strategy has to be sustainable, otherwise, the competitive advantage that is being developed will just provide temporary competitive advantage, so, such resources have to be perfectly inimitable and non-duplicable or subject to direct substitution. Further more, if such resources are held or copied by another firm, the resources will not provide sustainable competitive advantage (Barney, 1991). If a firm only relies on tangible resources such as plant 
equipment, raw material or funds as their competitive advantage, these resources might not lasts, as globalization provides the opportunity for other firms to access those resources easily. In this study, the respodents revealed that a focus on both tangible and intangible resource development that includes, funds, land, technology, a skilled workforce, policy and brands reputation is likely to generate the most growth within the seed industry. The respodents also agreed that firms with valuable resources stand a better chance of growth but in view of the contraints and limitations of their capacity and they must encourage support from the government, particularly on intangible resources.

There is a strong indication of need, in further developing the seed industry in Malaysia. Developing this industry requires a multiple dimension approach to resources and it was clear that intangible resources stand a better chance of sustaining a competitive advantage which would lead to the growth of the seed industry in Malaysia.

\section{REFERENCES}

Farquhar, J.D. (2012) Case Study Research for Business. Sage. London.

Geertz, C. (1983). Local Knowledge: Further Essays in Interpretative Anthropology. New York: Basic Books.

Greene, P. G., \& Brown, T.E. (1997), Resource needs and the dynamic capitalism, Lok Sahitya Kendra, Jodhpur, India. Management Perspectives, Oxford and IBH Pvt. New Delhi. Management, 17(1): 99-120.

Hoskisson, R. E., Hitt, M. A., Wan, W. P., \& Yiu, D. (1999). Theory and research in strategic management: Swings of a pendulum. Journal of Management, 25 (3), 417-456.

Jay Barney (1991), Firm resources and sustained competitive advantage, Sage Publications. Journal of Management, 17(1): 99-120.

Maxwell, J. A. (1996). Qualitative Research Design: An Interactive Approach. Thousand Oaks, CA: Sage Publications.

Melor, R. (2003). Varieties, Improvement of Solanaceous Vegetable: Current Achievement, Constraint and Strategies, 3rd National Seed Symposium, University Putra Malaysia, Kuala Lumpur, Malaysia, 51-57.

Nasir, N., Muhammad, S. J., Sarfraz, H., \& Sultan, A. A., (2010), Decade wise analysis of total factor productivity growth of agriculture sector, Analysis of productivity growth in agriculture, 92106.

Penrose, E. (1959). The Theory of the Growth of the Firm. New York: Wiley. 
Porter, M. E. (1991). Toward A Dynamic Theory of Strategy. Strategic Management Journal, 12(5): 95-117.

Porter, M. E. (1996). What is Strategy, Harvard Business Review, 14(1): 179-191.

Rumelt, Richard P., Dan Schendel, and David Teece (1991), "Strategic Management and Economics," Strategic Management Journal, 12 (Winter), 5-30.

Singh, G., Asokan, J. K. \& Asopa, V. H. (1990). Seed Industry of India: A Management Perspective. Strategic Management Journal, 15(2): 98-118.

Wernerfeldt, B. (1984). The resource-based view of the firm. Strategic Management Journal, 5, 171180. 